\title{
Identifikasi Carmovirus pada Tanaman Anyelir melalui Teknik Reverse Transcription-Polymerase Chain Reaction dan Analisis Sikuen Nukleotida
}

\author{
Identification of Carmovirus Infecting Carnation Using \\ Reverse Transcription-Polymerase Chain Reaction \\ and Analysis of Nucleotide Sequences
}

\author{
Rizki Haerunisa, Erniawati Diningsih, Gede Suastika* \\ Institut Pertanian Bogor, Bogor 16680
}

\begin{abstract}
ABSTRAK
Gejala belang pada daun tanaman anyelir (Dianthus caryphyllus) ditemukan di daerah Cianjur dan Bandung, Jawa Barat. Penelitian dilakukan untuk mengidentifikasi virus penyebab penyakit belang pada tanaman anyelir dengan menggunakan teknik reverse transcription-polymerase chain reaction (RTPCR) dan analisis sikuen nukleotida. Pita DNA berukuran $1000 \mathrm{pb}$ berhasil diamplifikasi menggunakan primer spesifik protein selubung Carmovirus (BC57/BC58). Produk PCR tersebut digunakan untuk mendapatkan sikuen nukleotida. Analisis sikuen nukleotida membuktikan bahwa penyakit belang pada tanaman anyelir disebabkan oleh infeksi Carnation mottle virus (CarMV). Analisis filogenetika menunjukkan bahwa isolat CarMV asal Indonesia memiliki hubungan kekerabatan yang dekat dengan isolat CarMV asal Belanda, Brazil, India, Iran, Israel, dan Spanyol.
\end{abstract}

Kata kunci: Carnation mottle virus, filogenetika, penyakit belang, protein selubung

\begin{abstract}
Mottle disease of carnation (Dianthus caryophyllus) was observed in cultivation areas in Cianjur and Bandung, West Java. This study aimed to identify the virus causing leaf mottling on carnation using reverse transcription-polymerase chain reaction (RT-PCR) method and nucleotide sequence analysis. Fragment DNA of 1000 bp was successfully amplified using specific primers for coat protein of Carmovirus (BC57/BC58). Direct sequencing was proceeded using PCR products. Nucleotide sequence analysis confirmed the infection of Carnation mottle virus (CarMV) from leaves showing mottle symptom. Furthermore, phylogenetic analysis showed that CarMV isolates from Indonesia have close relationship with those from Brazil, Israel, Iran, India, Netherland, and Spain.
\end{abstract}

Key words: Carnation mottle virus, coat protein, mottle disease, phylogenetic

\section{PENDAHULUAN}

Anyelir(Dianthus caryophyllus) merupakan salah satu tanaman bunga potong dengan nilai ekonomi tinggi di dunia. Permintaan anyelir meningkat untuk berbagai keperluan seperti hiasan, dekorasi ruangan, dan ucapan selamat (Tah dan Mamgain 2013). Salah satu kendala produksi bunga anyelir ialah adanya gangguan organisme pengganggu tanaman (OPT). Infeksi virus dapat menyebabkan penurunan kualitas bunga hingga mempengaruhi

*Alamat penulis korespondensi: Departemen Proteksi Tanaman, Fakultas Pertanian, Institut Pertanian Bogor Jalan Kamper, Kampus Darmaga IPB, Bogor 16680

Tel: 0251-8629364, Faks: 0251-8629362, Surel: gedesuast@yahoo.com 
produksi, penjualan, dan keuntungan pasar. Carnation mottle virus (CarMV) merupakan virus utama pada pertanaman anyelir dan sudah tersebar luas di seluruh pertanaman anyelir di dunia (Singh et al. 2005; Cevik et al. 2010). Kisaran inang CarMV terbatas hanya pada tanaman anyelir, namun CarMV dilaporkan juga menginfeksi anggrek Phalaenopsis dan Calla lily di Taiwan (Chen dan Ko 2003; Zheng et al. 2011).

Di Indonesia beberapa tanaman anyelir ditemukan menunjukkan gejala infeksi virus. Gejala yang timbul berupa mosaik ringan pada daun, belang kuning kehijauan pada lamina daun, tulang daun berwarna hijau tua, serta tepi daun terlihat sedikit melekuk. Gejala tersebut sangat mirip dengan deskripsi gejala infeksi CarMV yang dilaporkan sebelumnya di beberapa negara. Penelitian dilakukan untuk mengidentifikasi CarMV pada tanaman anyelir melalui metode reverse transcription polymerase chain reaction (RT-PCR) dan analisis sikuen nukleotida.

\section{BAHAN DAN METODE}

\section{Pengambilan Sampel Tanaman Anyelir}

Sampel tanaman anyelir bergejala penyakit yang disebabkan oleh virus diperoleh dari kebun petani di Desa Cihideung, Kecamatan Parongpong, Kabupaten Bandung dan dari Kebun Percobaan Balai Penelitian Tanaman Hias Desa Cipanas dan Desa Ciputri di Kecamatan Pacet, Kabupaten Cianjur. Sampel tersebut disimpan pada suhu $-80^{\circ} \mathrm{C}$.

\section{Deteksi Carmovirus melalui RT-PCR}

Ekstraksi RNA total dilakukan menggunakan Bench-Top Protocols for Xprep Plant RNA Mini Kit (PKT Korea). Hasil ekstraksi RNA total digunakan sebagai templat pada tahap transkripsi balik untuk memperoleh cDNA (complementary DNA). Setiap reaksi transkripsi balik (total volume $10 \mu \mathrm{L}$ ) terdiri atas $2 \mu \mathrm{L}$ total RNA, $3.7 \mu \mathrm{L} \mathrm{H}_{2} \mathrm{O}, 2 \mu \mathrm{L}$ bufer enzim M-MuLV Rev $10 \mathrm{x}, 0.35 \mu \mathrm{L} 50 \mathrm{mM}$ DTT, $0.5 \mu \mathrm{L} 10 \mathrm{mM}$ dNTP, $0.35 \mu \mathrm{L}$ enzim M-MuLV Rev, $0.35 \mu \mathrm{L}$ RNase inhibitor, dan $0.75 \mu$ Loligo d(T) 10 mM. Reaksi transkripsi balik dilakukan menggunakan automated thermal cycler (Gene Amp PCR System 9700; PE Applied Biosystem, USA) yang diprogram untuk satu siklus pada suhu $25{ }^{\circ} \mathrm{C}$ selama 5 menit, $42{ }^{\circ} \mathrm{C}$ selama 60 menit, dan $70{ }^{\circ} \mathrm{C}$ selama 15 menit. Hasil akhir transkripsi balik berupa cDNA digunakan sebagai DNA templat dalam reaksi amplifikasi.

Amplifikasi cDNA virus dilakukan dengan metode PCR dengan pasangan primer spesifik untuk mendeteksi sebagian gen protein selubung Carmovirus, yaitu BC57 (5' GATCGCGATGAATCCCACTGTGC 3') dan BC58 (5' TCACATCCTATAAACAACCAT TG 3'), dengan perkiraan ukuran produk amplifikasi sebesar 1000 pb. Reaksi amplifikasi (total volume $25 \mu \mathrm{L}$ ) terdiri atas $1 \mu \mathrm{L}$ DNA templat, $1 \mu \mathrm{L}$ primer BC57 $(10 \mu \mathrm{m}), 1 \mu \mathrm{L}$ primer BC58 $(10 \mu \mathrm{m}), 12.5 \mu \mathrm{L}$ Go Taq Green Master Mix 2 x (Promega, Madison, USA), dan 9.5 $\mu \mathrm{L} \mathrm{H}_{2} \mathrm{O}$. Amplifikasi DNA menggunakan automated thermal cycler dengan diawali tahapan denaturasi awal pada $94{ }^{\circ} \mathrm{C}$ selama 3 menit. Tahapan selanjutnya ialah sebanyak 35 siklus yang terdiri atas denaturasi pada $94^{\circ} \mathrm{C}$ selama 30 detik, penempelan primer pada $50{ }^{\circ} \mathrm{C}$ selama 1 menit, sintesis pada $72{ }^{\circ} \mathrm{C}$ selama 1 menit 10 detik dan ditambahkan 10 menit pada $72{ }^{\circ} \mathrm{C}$ untuk tahap sintesis akhir (Cevik et al. 2010).

Visualisasi hasil amplifikasi DNA menggunakan gel agarosa 1\% dalam $25 \mathrm{~mL}$ bufer Tris-Borat EDTA (TBE) $0.5 \mathrm{x}$. Sebanyak $7 \mu \mathrm{L}$ penanda DNA $(1 \mathrm{~kb})$ dan $7 \mu \mathrm{L}$ DNA hasil amplifikasi dimasukkan ke dalam sumuran gel agarosa. Elektroforesis dilakukan pada tegangan 100 volt selama 30 menit dan hasil elektroforesis diamati di bawah transluminator ultraviolet.

\section{Analisis Sikuen Nukleotida}

Hasil amplifikasi DNA dikirim ke PT Macrogen Inc. (Seoul, Korea) untuk sikuensing. Hasil sikuensing digunakan untuk analisis kesejajaran dengan sikuen Carmovirus pada GenBank dengan program basic local alignment search tool (BLAST) pada situs National Center for Biotechnology Information (NCBI), kemudian dianalisis lanjut dengan 
program clustal $W$ multiple alignment pada software BioEditV7.0.5. Analisis filogenetika dilakukan dengan program molecular evolutionary genetics analysis (MEGA 5.05).

\section{HASIL}

\section{Penyakit Belang pada Tanaman Anyelir di Lapangan}

Pertanaman anyelir di Cianjur dan Bandung yang bergejala infeksi virus diamati dengan gejala khas penyakit berupa belang daun berwarna hijau muda dengan batas yang tidak jelas (Gambar 1a), belang pada lamina daun berwarna kuning kehijauan dan tulang daun berwarna hijau tua yang cukup jelas dengan tepi daun sedikit melekuk (Gambar 1b). Gejala tersebut banyak ditemukan pada tanaman di pembibitan seperti yang ditemukan di
Cipanas dan Ciputri, tetapi gejala serupa tidak ditemukan di daerah Cihideung, Parongpong (Gambar 1c).

\section{Deteksi Carmovirus melalui RT-PCR}

Pita DNA berukuran 1000 pb berhasil diamplifikasi dari sampel daun asal Cipanas, Ciputri dan Cihideung (Gambar 2). Dari daerah Cipanas diperoleh 4 jenis anyelir sebagai sampel untuk deteksi, pita DNA hanya berhasil diamplifikasi dari sampel klon RS 0313 dan klon MD 761, tidak berhasil diamplifikasi dari sampel klon Dianthus barbatus Jatim dan klon RS 83.1. Pita DNA berhasil diamplifikasi dari sampel asal Ciputri dan Cihideung, yaitu berturut-turut anyelir tipe standar 'White Candy' dan tipe standar 'Salem'. Hasil deteksi dengan metode RT-PCR menggunakan primer spesifik Carmovirus memastikan bahwa gejala

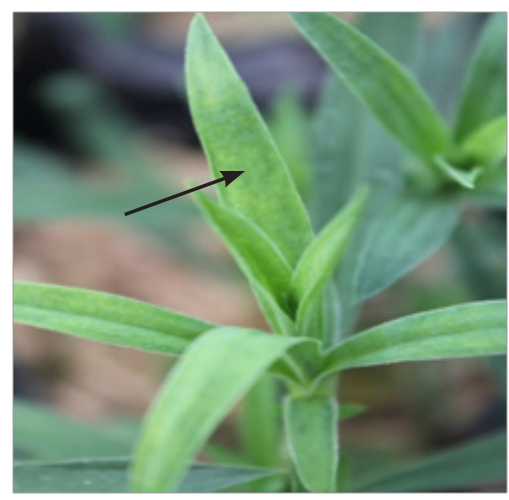

a

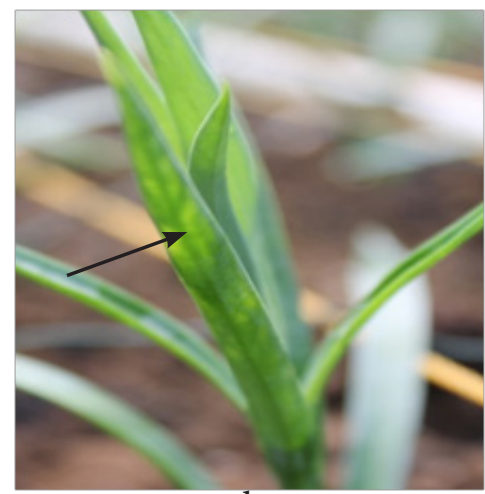

b

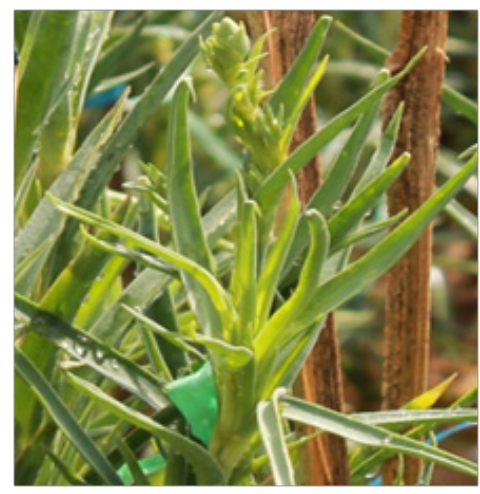

C

Gambar 1 Gejala Carnation mottle virus pada tanaman anyelir (Dianthus caryophyllus) berupa belang daun: a, Cipanas; b, Ciputri; dan c, Cihideung.

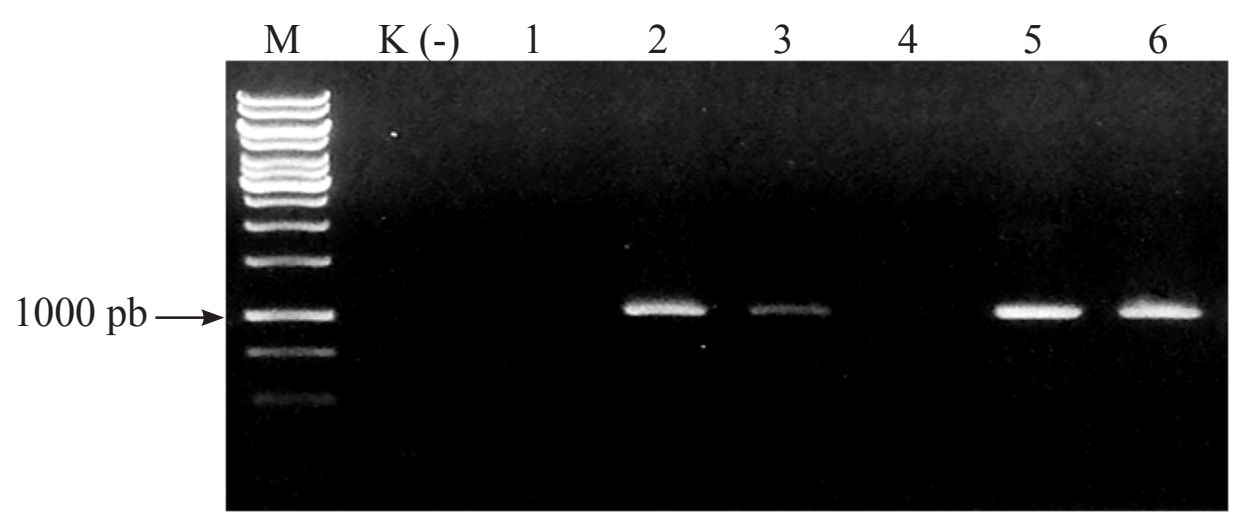

Gambar 2 Pita DNA hasil amplifikasi dari tanaman anyelir menggunakan primer spesifik Carmovirus. M, penanda DNA 1 kb (Promega, USA); K-, kontrol negatif(tanaman sehat); 1, 2, 3, dan 4 tanaman anyelir asal Cipanas, berturut-turut varietas Dianthus barbatus Jatim, klon RS 0313, klon MD 76113, dan klon RS 83.1; 5, tanaman anyelir asal Ciputri (tipe standar 'White Candy'); 6, tanaman anyelir asal Cihideung (tipe standar 'Salem'). 
belang pada tanaman anyelir merupakan gejala infeksi Carmovirus. Penelitian lanjut digunakan tiga isolat virus yang berbeda asalnya, selanjutnya disebut isolat virus Cipanas, Ciputri, dan Cihideung.

\section{Identifikasi Spesies Carmovirus berdasarkan Homologi Sikuen Nukleotida}

Berdasarkan analisis menggunakan program BLAST berhasil diidentifikasi isolat Carmovirus asal tanaman anyelir dari Cipanas, Ciputri, dan Cihideung yang memiliki tingkat homologi tinggi (>97\%) dengan CarMV dari Australia, Belanda, Brazil, Jepang, Spanyol, India, Iran, Israel, Kolombia, dan Perancis (Tabel 1). Persentase homologi tertinggi (98.7\%) adalah antarisolat Ciputri, Cihideung, dan Cipanas. Hal ini menunjukkan bahwa isolat virus asal Cipanas, Ciputri, dan Cihideung merupakan kelompok virus yang kekerabatannya sangat dekat. Jika dibandingkan dengan isolat virus dalam GenBank, isolat Cipanas memiliki tingkat homologi yang tinggi dengan CarMV isolat Nl-2 (Belanda), yaitu 98.3\%. Isolat Ciputri memiliki tingkat homologi tertinggi (97.9\%) dengan CarMV isolat N1-2 dan CarMV isolat Mahallat-2 (Iran). Isolat Cihideung memiliki tingkat homologi tertinggi $(97.9 \%)$ dengan CarMV isolat Isr-2 (Israel). Dengan demikian dapat disimpulkan bahwa spesies Carmovirus yang menginfeksi tanaman anyelir di daerah Cianjur dan Bandung adalah CarMV.

\section{Analisis Filogenetika Spesies Carmovirus}

Analisis kekerabatan berdasarkan sikuen nukleotida menunjukkan bahwa isolat CarMV membentuk dua kelompok utama (Gambar 3). Pada kelompok pertama, isolat Indonesia yang berasal dari Cipanas, Ciputri, dan Cihideung membentuk satu subkelompok, sedangkan isolat CarMV asal Brazil, Israel, Iran, India, Belanda, dan Spanyol membentuk subkelompok yang terpisah. Kelompok 2 terdiri atas isolat CarMV asal Australia, Jepang, Kolombia, dan Perancis. Analisis filogenetika ini menunjukkan bahwa CarMV isolat Cipanas, Ciputri, dan Cihideung memiliki kekerabatan yang sangat dekat dengan kelompok spesies CarMV dari negara lain.

\section{PEMBAHASAN}

Gejala belang pada tanaman anyelir di Cipanas dan Ciputri banyak ditemukan pada fase pembibitan. Gejala serupa pernah dilaporkan Waterworth dan Kaper (1972) pada Dianthus barbatus di Maryland, Amerika Serikat, yaitu berupa mosaik ringan. Pertanaman di daerah Cihideung sudah memasuki fase generatif dan gejala belang tidak ditemukan, namun sampel daun yang tidak bergejala tersebut telah dikonfirmasi positif terinfeksi Carmovirus melalui deteksi PCR. Beberapa penelitian terdahulu melaporkan bahwa gejala infeksi Carmovirus pada pertanaman anyelir berupa mosaik ringan pada daun muda yang tidak begitu jelas, sedangkan pada tanaman yang telah berbunga tidak terlihat adanya gejala (Lommel et al. 1983; Singh et al. 2005). Infeksi CarMV tidak menginduksi gejala atau hanya menimbulkan gejala ringan, namun akan mengakibatkan tanaman menjadi lemah sehingga dapat diinfeksi oleh patogen lainnya (Safari et al. 2009). CarMV dapat ditularkan melalui organ perbanyakan tanaman, alatalat pertanian, kontak antartanaman, namun tidak dapat ditularkan melalui vektor serangga (Singh et al. 2005; Safari et al. 2009).

Di Indonesia belum ada laporan mengenai insidensi penyakit belang yang disebabkan oleh CarMV, namun beberapa penelitian mulai dilakukan sebagai upaya pengendalian penyakit ini. Stone (2008) melaporkan keberhasilan eleminasi CarMV dari tanaman anyelir melalui teknik kultur meristem. Distribusi stek tanaman sebagai bahan propagasi anyelir dari satu daerah ke daerah lain dapat menyebabkan penyebaran CarMV. Oleh karena itu, rekomendasi pengendalian penyakit belang pada anyelir ialah dengan penggunaan benih bebas virus yang diperoleh melalui teknik kultur jaringan. 


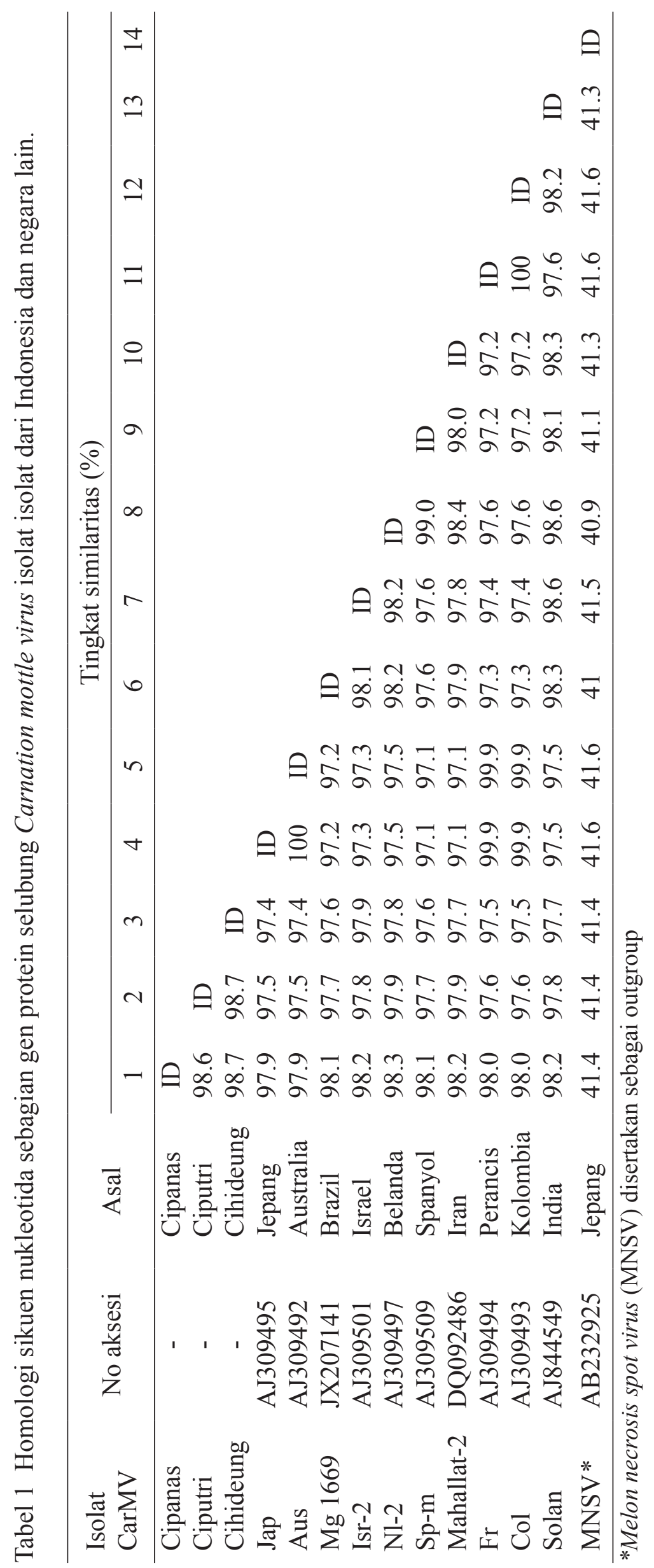




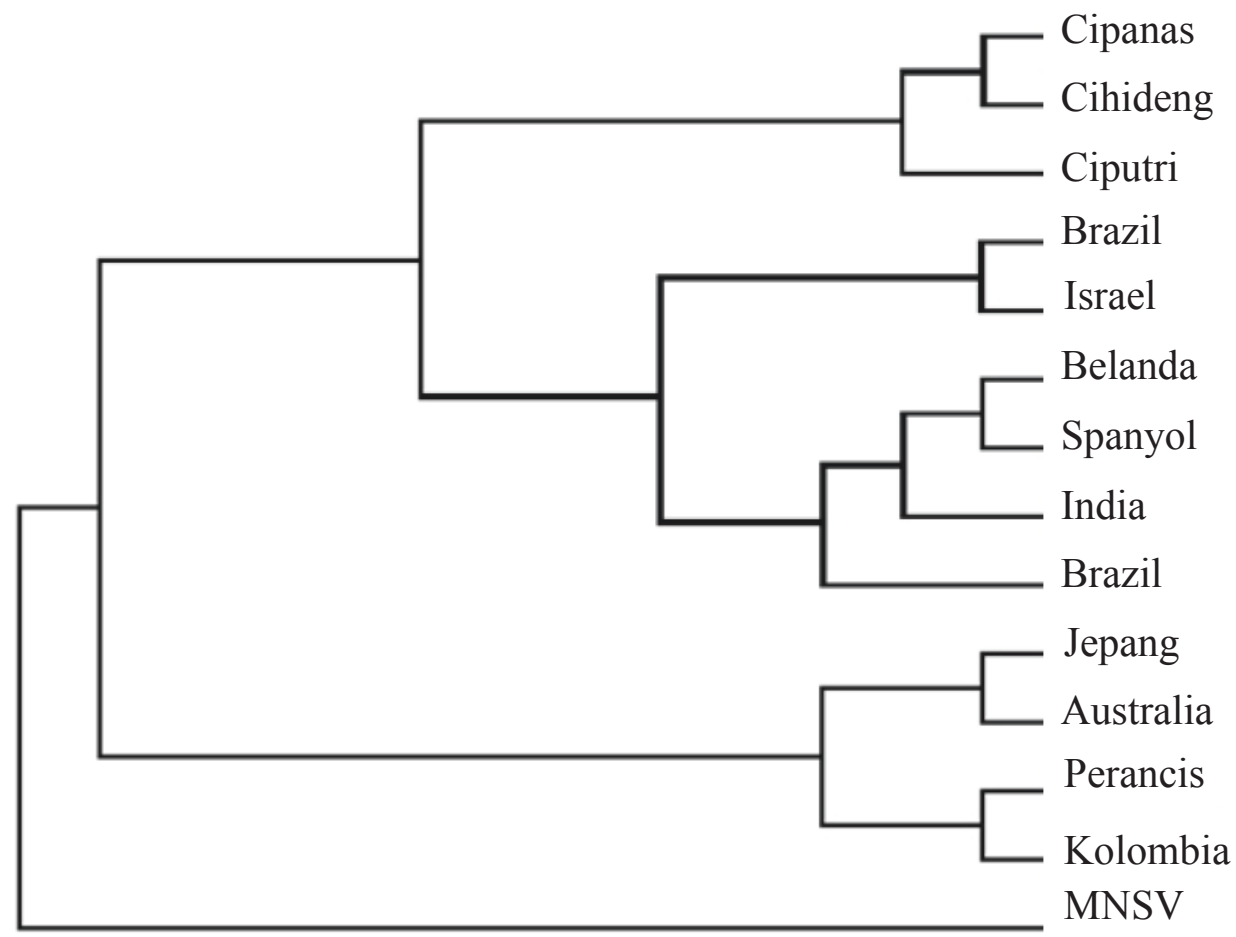

Gambar 3 Kladogram berdasarkan sikuen nukleotida sebagian gen protein selubung Carnation mottle virus isolat Cipanas, Cihideung, dan Ciputri dari Indonesia dan negara lain menggunakan program MEGA 5.05. Melon necrosis spot virus (MNSV) disertakan sebagai out group.

\section{DAFTAR PUSTAKA}

Cevik B, Bakir T, Koca G. 2010. First report of Carnation mottle virus in Turkey. Plant Pathol. 59(2):394. DOI: http://dx.doi. org/10.1111/j.1365-3059.2009.02181.x.

Chen CC, Ko WF. 2003. First report of Carnation mottle virus in Calla lily (Zantedeschia spp.). Plant Dis. 87(12):1539. DOI: http://dx.doi.org/10.10 94/PDIS.2003.87.12.1539C.

Lommel SA, McCain AH, Mayhew DE, Morris TJ. 1983. Survey of commercial carnation cultivars for four viruses in California by indirect enzyme-linked immunosorbent assay. Plant Dis. 67(1):53-56. DOI: http:// dx.doi.org/10.1094/PD-67-53.

Safari M, Habibi MK, Mosahebi G, Dizadji A. 2009. Carnation mottle virus, an important viral agent infecting carnation cut-flower crops in Mahallat of Iran. Commun Agric Appl Biol Sci. 74(3):861-865.

Singh HP, Hallan V, Raikhy G, Kulshrestha S, Sharma ML, Ram R, Garg ID, Zaidi AA. 2005. Characterization of an Indian isolate of Carnation mottle virus infecting carnations. Current Sci. 88(4):594-601.

Stone OM. 2008. The elimination of four viruses from carnation and sweet william by meristem-tip culture. Ann Appl Biol. 62(1):119-122. DOI: http://dx.doi.org/10. 1111/j.1744-7348.1968.tb03855.x.

Tah J, Mamgain A. 2013. Variation in different agronomical characters of some carnation (Dianthus caryophyllus) cultivars. Res J Biol. 1:10-23.

Waterworth HE, Kaper JM. 1972. Purification and properties of Carnation mottle virus and its ribonucleic acid. Phytopathology. 62(9):959-964. DOI: http://dx.doi.org/10. 1094/Phyto-62-959.

Zheng YX, Chen CC, Jan FJ. 2011. First report of Carnation mottle virus in Phalaenopsis Orchids. Plant Dis. 95(3):354. DOI: http:// dx.doi.org/10.1094/PDIS-10-10-0757. 